\title{
Think Pair Share sebagai Strategi Efektif dalam Pembelajaran Membaca Intensif Siswa SMP
}

Made Astiti Aryasih*

SMP Negeri 3 Sawan, Buleleng, Indonesia

A R T I C L E I N F O

Article history:

Received 19 May 2018

Received in revised form

25 June 2018

Accepted 10 July 2018

Available online 25

August 2018

\section{Kata Kunci:}

Strategi Pembelajaran;

Think Pair Share; Hasil

Belajar; Membaca

Intensif; Bahasa

Indonesia

Keywords:

Learning Strategies;

Think Pair Share;

Learning Outcomes;

Intensive reading;

Indonesian

\begin{abstract}
A B S T R A K
Tujuan penulisan penelitian tindakan ini adalah untuk meningkatkan hasil belajar membaca intensif pada siswa kelas VII A4 SMP Negeri 3 Sawan melalui penerapan strategi pembelajaran Think Pair Share. Mengacu kepada permasalahan yang akan ditanggulangi melalui penelitian, maka jenis penelitian yang digunakan adalah penelitian tindakan kelas melalui dua siklus dengan tahapan; perencanaan, pelaksanaan, observasi dan refleksi. Metode pengumpulan datanya adalah tes menjawab soal wacana. Metode analisis datanya adalah deskriptif. Hasil yang diperoleh dari penelitian ini adalah strategi TPS dapat meningkatkan kemampuan membaca intensif pada siswa. Ini terbukti dari hasil belajar yang diperoleh dalam membaca intensif siswa. Pada refleksi awal rata-rata nilai membaca intensif siswa sebesar 73,08 dengan ketuntasan 38,46 \% dan pada siklus I nilai rata-rata siswa meningkat menjadi 76,73 dengan ketuntasan 72,00\% walaupun masih dalam kategori cukup tapi sudah ada peningkatan pada nilai rata-rata siswa sebesar $3,65 \%$. Setelah dilaksanakan perbaikan tindakan pada siklus II, rata-rata nilai membaca intensif siswa pada siklus II sebesar 80,77 mengalami peningkatan sebesar 4,04\% dari Siklus I dan berada pada kategori baik dan seluruh siswa tuntas. Kesimpulan dari penelitian ini adalah bahwa Penerapan strategi pembelajaran Think Pair Share dapat meningkatkan hasil belajar membaca intensif bagi siswa kelas VII A4 SMP Negeri 3 Sawan.
\end{abstract}

\section{A B S T R A C T}

The purpose of writing this action research was to improve the results of intensive reading learning for class VII A4 students of SMP Negeri 3 Sawan through the application Think Pair Share learning strategies. Referring to the problems that will be addressed through research, the type of research used is classroom action research through two cycles with stages; planning, implementation, observation, and reflection. The data collection method is a test to answer the question of discourse. The data analysis method is descriptive. The results obtained from this study are the TPS strategy can improve intensive reading skills in students. It is evident from the learning outcomes achieved in intensive student reading. In the initial reflection the average score of students' intensive reading was 73.08 with $38.46 \%$ completeness, and in the first cycle, the average rating of students increased to 76.73 with $72.00 \%$ completeness even though it was still in the sufficient category, but there was an increase in the average student score is $3.65 \%$. After the improvement of actions in cycle II, the average score of intensive reading of students in the second cycle of 80.77 increased by $4.04 \%$ from Cycle I and was in good category and all students complete. The conclusion from this study is that the application of Think Pair Share learning strategies can improve the results of intensive reading learning for class VII A4 students of SMP Negeri 3 Sawan.

\footnotetext{
* Corresponding author.

E-mail addresses: astitiaryasih66@gmail.com
} 


\section{Pendahuluan}

Kurikulum Tingkat Satuan Pendidikan di SMP Negeri 3 Sawan semester genap tahun pejaran 2016/2017, khususnya pada mata pelajaran Bahasa Indonesia, ketuntasan belajar siswa ditentukan berdasarkan Kriteria Ketuntasan Minimal (KKM) 75,00. Dalam upaya pencapaian kriteria ketuntasan minimal tersebut semestinya kegiatan pembelajaran yang dirancang dan diterapkan mampu memberdayakan siswa untuk belajar sehingga terjadi pengkonstruksian secara optimal. Tetapi dalam pelaksanaan pembelajaran di kelas, antara Rencana Pelaksanaan Pembelajaran (RPP) yang disusun dengan kegiatan pembelajaran belum sesuai. Guru masih mendominasi kegiatan pembelajaran dengan ceramah untuk semua kompetensi dan memberikan tugas terstruktur. Selama kegiatan pembelajaran prasiklus, semua informasi atau data terkait materi yang dibelajarkan disampaikan oleh guru dan siswa diwajibkan untuk memperhatikan dan mencatat penjelasan guru. Pada akhir kegiatan pembelajaran semua siswa diberikan individu (tugas terstruktur) sesuai materi yang sudah dibelajarkan.

Pembelajaran bahasa Indonesia diarahkan untuk meningkatkan kemampuan berkomunikasi peserta didik dalam bahasa Indonesia yang baik dan benar, baik secara lisan maupun tertulis. Standar kompetensi pembelajaran bahasa Indonesia merupakan kualifikasi kemampuan minimal peserta didik yang menggambarkan penguasaan pengetahuan keterampilan berbahasa dan sikap positif terhadap Bahasa dan Sastra Indonesia. Dalam pembelajaran, mata pelajaran bahasa Indonesia mencakup komponen kemampuan bersasastra yang meliputi 4 aspek, yaitu mendengarkan, berbicara, membaca, dan menulis (KTSP, 2007).

Dari keempat keterampilan berbahasa tersebut keterampilan membaca secara oprasional memiliki peranan yang sangat penting dalam memahami isi bacaan. Dalam pembelajaran membaca di sekolah siswa dituntut untuk memahami isi bacaan, seperti menjawab pertanyaan yang berkaitan dengan isi bacaan, menemukan gagasan utama dalam bacaan, dan merangkum isi bacaan. Kemampuan membaca dan memahami isi bacaan sangat penting dikuasi siswa, karena kemampuan ini dibutuhkan untuk menyelesaikan tugas-tugas yang diberikan oleh guru, seperti menjawab pertanyaan, meringkas serta untuk menambah pengetahuan tentang pelajaran yang diajarkan di sekolah. Sukses dalam membaca sangat penting bagi siswa dalam rangka mengembangkan kemampuan akademik, keahlian, dan kecerdasan (Carnine dalam Sudiana, 2007). Sementara itu Yunus, (dalam Sudiana, 2007) tidak meragukan bahwa membaca merupakan kunci keberhasilan seorang siswa. Baginya membaca merupakan faktor penting dalam segala usaha pembelajaran.

Kemampuan membaca yang baik dan benar sangat penting peranananya dalam membantu anak mempelajari berbagai hal (Sudiana, 2007). Melalui aktivitas mambaca yang baik dan benar, anak akan mampu mengambil intisari dari bahan yang dibacanya. Dengan demikian anak bisa mendapatkan sesuatu dari aktivitas membaca yang dilakukannya. Semakin besar intisari yang bisa dipahami dari isi bacaan semakin banyak pula pengetahuan yang diperoleh. Banyaknya pengetahuan ini akan sangat membantu anak dalam menjalani kehidupanya di masa depan. Selain itu, kemampuan nalar anak akan berkembang dengan pesat ketika anak berhasil mendapat informasi melalui bahan bacaan. Dengan membaca dapat dibuka cakrawala ilmu pengetahuan, teknologi, dan seni serta wawasan tentang dunia luar yang menyimpan sejuta misteri. Selain itu informasi yang berkembang sangat pesat bisa diperoleh melalui membaca (Harjasujana dan Mulyati, 1996).

Kemampuan membaca bukanlah kemampuan yang diwariskan secara turun menurun, walaupun pada dasarnya manusia memiliki kemampuan secara alamiah. Manusia mampu membaca jika berlatih. Namun membaca secara intensif memerlukan pelatihan dan pengarahan atau pembimbingan yang khusus. Karena membaca intensif merupakan membaca secara cermat untuk memahami suatu teks atau isi bacaan secara tepat dan akurat (Arini, 2006). Untuk meningkatkan kemampuan membaca, maka perlu adanya upaya perbaikan terhadap proses pembelajaran. Proses pembelajaran yang baik hendaknya dapat menumbuhkan minat, motivasi, dan aktivitas belajar. Untuk menciptakan pembelajaran seperti itu, guru harus kreatif baik dalam pemilihan strategi pembelajaran, media pembelajaran, maupun dalam menciptakan suasana yang kondusif di dalam kelas pada saat proses pembelajaran agar dapat menarik minat siswa dalam pembelajaran membaca (Abimanyu, 2008).

Kendala-kendala yang dialami yaitu konsentrasi siswa ketika mengikuti proses pembelajaran tidak bertahan lama tetapi mereka cenderung sibuk sendiri, saat berdiskusi siswa cendrung bercanda ataupun ngobrol dengan temannya, ketika guru menjelaskan materi pelajaran, siswa cepat merasa bosan, dan rendahnya motivasi untuk belajar. Ini berdampak pada kemampuan siswa dalam membaca dan memahami isi bacaan, siswa hanya sekedar membaca tanpa dapat memahami isi teks bacaan secara mendalam. Akibatnya, hanya 36,46 \% siswa kelas VII A4 memperoleh nilai sesuai KKM pada mata pelajaran Bahasa Indonesia khususnya dalam aspek membaca sesuai kriteria ketuntasan minimal (KKM). Kriteria ketuntasan minimal untuk aspek membaca yang ditetapkan MGMP bahasa Indonesia di Kelas VII 
SMP Negeri 3 Sawan adalah 75. Jika kendala-kendala dalam pembelajaran seperti di atas terus dibiarkan begitu saja, maka sudah tentu tujuan pembelajaran yang ditetapkan tidak akan tercapai secara optimal disamping itu jika kemampuan siswa dalam membaca dan memahami teks bacaan masih rendah ini akan berimbas pada pencapaian kompetensi siswa pada mata pelajaran yang lain. Hal ini disebabkan karena kemampuan membaca merupakan salah satu kemampuan dasar yang dapat menunjang pencapaian kompetensi siswa dalam berbagai mata pelajaran.

Berdasarkan uraian tersebut, pengelolaan proses pembelajaran memegang peranan sangat penting guna mengaktifkan pembelajaran dan mencapai tujuan pembelajaran yang optimal. Salah satu pengelolaan proses pembelajaran dapat dilakukan melalui penerapan strategi pembelajaran secara tepat. Strategi pembelajaran dikatakan memegang peranan penting karena strategi pembelajaran menunjuk kepada pengaturan (memilih, menyusun dan memobilisasi) cara, sarana/prasarana dan tenaga untuk mencapai tujuan pembelajaran (Sudijarto dalam Abimanyu, 2008). Namun, penerapan strategi pembelajaran harus memperhatikan karakteristik peserta didik dan kesesuaiannya dengan materi pelajaran (Sanjaya, 2008).

Mengingat demikian pentingnya peranan strategi pembelajaran, maka peneliti berupaya untuk mengatasi permasalahan yang telah diuraikan di atas yakni dengan penerapan strategi pembelajaran Think Pair Share (TPS). Strategi pembelajaran Think Pair Share (TPS) dapat lebih mengembangkan kecakapan hidup sosial siswa. Strategi pembelajaran ini membuat siswa memiliki ketergantungan positif dengan teman satu kelompok, saling berbagi ide, mempunyai kesempatan yang sama dalam berpartisipasi dan lebih meningkatkan banyaknya informasi untuk diingat. Strategi pembelajaran Think Pair Share memberikan waktu kepada siswa untuk berfikir dan merespon serta saling bantu satu sama lain. Dengan Think diharapkan siswa bisa membaca dan memikirkan sendiri isi atau pokok bahasan dari bacaan tersebut, Pair siswa mendiskusikan hasil pemikirannya dengan seorang mitra, dan Share siswa berbagi hasil diskusinya pada tahap pairing dengan seluruh siswa satu kelas.

Berdasarkan latar belakang di atas penelitian ini mencoba menerapkan strategi pembelajaran Think Pair Share untuk Meningkatkan Hasil Belajar Membaca Intensif Siswa Kelas VII A4 SMP Negeri 3 Sawan Semester Genap Tahun Pelajaran 2016/2017. Berdasarkan rumusan masalah yang telah dipaparkan di atas, tujuan penelitian ini adalah untuk meningkatkan hasil belajar membaca intensif siswa kelas VII A4 SMP Negeri 3 Sawan tahun ajaran 2016/2017 setelah diterapkannya strategi pembelajaran Think Pair Share.

\section{Metode}

Penelitian ini merupakan Penelitian Tindakan Kelas (PTK) atau Classroom Action Research. PTK memiliki peranan yang sangat penting dan strategis untuk meningkatkan mutu pelajaran melalui suatu tindakan bermakna dengan menggunakan sebuah model atau suatu pendekatan pembelajaran yang diperhitungkan dapat memecahkan masalah atau memperbaiki situasi dan kemudian secara cermat mengamati pelaksanaannya untuk mengukur tingkat keberhasilannya. Subyek penelitian adalah siswa kelas VII A4 SMP Negeri 3 Sawan semester genap tahun pelajaran 2016/2017 yang berjumlah 26 orang siswa. Dalam penelitian ini objek penelitiannya adalah peningkatan hasil belajar Bahasa Indonesia siswa kelas VII A4 semester genap SMP Negeri 3 Sawan. Pelaksanaan penelitian ini dijadwalkan dari bulan Januari sampai bulan April 2017

Adapun metode pengumpulan data yang akan digunakan dalam penelitian ini adalah dengan menggunakan Metode Tes. Tes biasanya diberikan pada setiap akhir kegiatan pembelajaran. Menurut Poerwanti (2008) tes diartikan sebagai himpunan pertanyaan yang harus dijawab, pernyataanpernyataan yang harus dipilih/ditanggapi, atau tugas-tugas yang harus dilakukan oleh peserta tes dengan tujuan untuk mengukur suatu aspek tertentu dari peserta tes. Sedangkan Nurkancana dan Sunartana (1990) mengungkapkan bahwa

Tes adalah suatu cara untuk mengadakan penilaian yang berbentuk suatu tugas yang dikerjakan oleh anak atau sekelompok anak sehingga menghasilkan suatu nilai tentang tingkah laku atau prestasi anak tersebut, yang dapat dibandingkan dengan nilai yang dicapai oleh anak-anak lain atau dengan nilai standar yang ditetapkan. Tes dalam penelitian ini digunakan untuk mengukur hasil belajar membaca intensif siswa kelas VII A4 adalah butir-butir tes yang sesuai dengan teks bacaan yang diberikan berupa tes pilihan ganda, dan untuk penskoran hasil tes menggunakan panduan evaluasi yang memuat kunci jawaban dan pedoman penskoran setiap butir soal yang terlampir pada lampiran 5 dan lampiran 10 . Metode pemberian tes yang digunakan mengacu pada Taksonomi Bloom seperti diungkapkan Harjasujana dan Mulyati (1996) untuk mengetahui atau mengukur hasil belajar membaca intensif siswa setelah penerapan strategi pembelajaran Think Pair Share. 
Adapun analisis yang dilakukan dalam penelitian ini menggunakan analisis deskriptif kuantitatif. Untuk data kuantitatif dianalisis dengan mencari mean, median, modus, membuat interval kelas dan melakukan penyajian dalam bentuk tabel dan grafik. Kriteria yang disampaikan dalam penelitian ini yang merupakan keberhasilan adalah apabila pada akhir siklus II rata-rata nilai siswa mencapai 75 atau lebih dengan ketuntasan belajar minimal $80 \%$.

\section{Hasil dan pembahasan}

Pelaksanaan pembelajaran di dalam kelas selama ini secara umum telah berlangsung sesuai dengan rencana pelaksanaan pembelajaran yang telah disusun sebagai penerapan strategi pembelajaran Think Pair Share. Penelitian ini dilaksanakan dalam 2 siklus. Setiap siklus dilaksanakan dalam 4 kali pertemuan, yaitu 3 kali pertemuan untuk pembelajaran dan 1 kali pertemuan untuk tes. Data yang dikumpulkan dalam penelitian ini, yaitu data tentang hasil belajar membaca intensif siswa terhadap pembelajaran yang dilaksanakan. Data yang telah dikumpulkan dianalisis sesuai dengan teknik analisis data yang telah ditetapkan sebelumnya. Adapun hasil dari analisis mengenai data tentang hasil belajar membaca intensif siswa terhadap pembelajaran yang dilaksanakan dijelaskan sebagai berikut.

\section{Kondisi Pra-Siklus}

Pada tahap awal, mencari dokumen nilai ulangan harian dari guru Bahasa Indonesia kelas VII A4 semester genap tahun pelajaran 2016/2017. Pencarian nilai ini dimaksudkan untuk mengetahui kelemahan yang dialami siswa pada salah satu aspek dari empat aspek keterampilan yang terdapat dalam bahasa Indonesia yang ternyata nilai yang paling rendah adalah aspek membaca khususnya dalam membaca intensif. Selain itu digunakan sebagai pertimbangan dalam melakukan penelitian dan menyusun ulangan harian sebelum tindakan. Perolehan nilai ulangan harian ini digunakan sebagai nilai awal dalam penelitian. Data nilai awal juga digunakan untuk mengetahui nilai kemajuan individu. Data ini digunakan untuk mengetahui bahwa di kelas tersebut hasil belajar Bahasa Indonesia dalam aspek membaca khususnya membaca intensif siswa masih rendah. Rata-rata nilai tes awal hasil belajar Bahasa Indonesia dalam aspek membaca khususnya membaca intensif siswa hanya 73,08 dan hanya 38,46 \% hasil belajar siswa sesuai dengan KKM, yaitu 75.

\section{Pembelajaran pada Siklus I}

1) Perencanaan Tindakan Siklus I

Berdasarkan refleksi awal, beberapa hal yang direncanakan dalam siklus I meliputi :

(1) Membaca beberapa teori tentang penerapan strategi pembelajaran Think Pair Share pada pembelajaran membaca intensif mata pelajaran bahasa Indonesia di kelas VII dan pedomanpedoman yang diberikan oleh Departemen Pendidikan dalam menyusun perencanaan agar mampu melaksanakan pembelajaran sesuai harapan.

(2) Menyusun rencana pelaksanaan pembelajaran (RPP) yang menggambarkan penerapan strategi pembelajaran Think Pair Share untuk tiga kali pertemuan dan menyusun alat evaluasi yang akan diberikan pada akhir siklus.

(3) Menyiapkan bahan-bahan pendukung pembelajaran seperti lembar kerja siswa (LKS) dan buku paket.

(4) Menyiapkan teks bacaan yang akan digunakan dalam proses pembelajaran.

(5) Menentukan jadwal pepenelitian yang disesuaikan dengan jadwal pelajaran di kelas VII I.

(6) Menyusun instrument penelitian berupa lembar observasi yang akan digunakan untuk menilai proses pembelajaran.

2) Pelaksanaan Tindakan Siklus I

Siklus I dilaksanakan dalam empat kali pertemuan. Tiga kali untuk pembelajaran dan satu kali untuk tes akhir siklus I.

(1) Pertemuan Pertama Pertemuan pertama dilaksanakan pada hari kamis tanggal 19 Januari 2017 sesuai dengan RPP 1. Pada pertemuan pertama ini materi yang dibahas adalah bagian-bagian tabel, isi tabel, menguraikan isi tabel, dan menyimpulkan isi tabel. Pembelajaran dimulai dengan melaksanakan kegiatan awal yaitu memberi salam, memantau kebersihan kelas, melakukan absensi, mempersiapkan siswa untuk belajar, memberi apersepsi, dan menginformasikan kepada siswa tentang tujuan pembelajaran dan materi yang akan dipelajari. Pembelajaran dilanjutkan dengan melaksanakan kegiatan inti yang dimulai dengan melakukan tanya jawab tentang bagian-bagian tabel, isi tabel, menguraikan isi tabel, dan menyimpulkan isi tabel. Langkah selanjutnya guru 
membagikan teks bacaan yang berjudul " Data Peminjam Buku Non Fiksi Perpustakaan SMP Negeri 3 Sawan" beserta soal-soal yang berkaitan dengan tabel tersebut.

Proses pembelajaran dilanjutkan pada tahap (Thinking). Pada tahap ini siswa dipersilakan untuk membaca tabel dalam hati sampai benar-benar paham kemudian dipersilakan menjawab soal-soal yang berkaitan dengan teks bacaan tersebut secara mandiri. Waktu yang di berikan pada tahap ini adalah 25 menit tapi waktu yang dihabiskan dalam tahap ini lebih lama. Ini disebabkan karena siswa kesulitan dalam menjawab soal-soal yang diberikan.

Pada tahap kedua yaitu tahap (Pairing) siswa diminta bekerja secara berpasangan atau berkelompok dengan teman sebangku untuk mendiskusikan apa yang telah dipikirkan pada tahap Thinking. Pada saat siswa diminta bekerja sama secara berpasangan dengan teman sebangku terjadi kesulitan karena sebagian siswa kurang setuju dengan pembagian kelompok yang dilakukan sehingga suasana menjadi ricuh dan waktu lebih lama terlewatkan untuk memasangkan siswa. Saat melakukan diskusi kebanyakan siswa tidak mau berbagi informasi tentang pemahaman mereka terhadap isi tabel yang mereka baca karena siswa belum terbiasa berbagi informasi dalam belajar kelompok.

Setelah melaksanakan diskusi secara berpasangan, pembelajaran masuk pada tahap selanjutnya yaitu tahap (Sharing). Siswa diberi kesempatan untuk saling berbagi informasi hasil diskusinya dengan seluruh teman di kelas. Pada tahap ini hanya 2 pasang atau 2 kelompok yang berani tampil ke depan. Saat penyajian hasil dikusi, siswa dapat menyampaikan ide atau pendapat, memberi tanggapan atas pertanyaan teman, dan bertanya terhadap hasil kerja yang diperoleh kelompok lain. Namun, pelaksanaan kegiatan pada tahap ini kurang optimal karena kebanyakan siswa enggan memberikan tanggapan ide atau pendapat yang disampaikan temannya serta waktu yang tersedia tidak mencukupi.

Setelah itu dilakukan penyimpulan hasil diskusi yang dilakukan siswa. Guru memberikan umpan balik positif dan penguatan dalam bentuk lisan, yaitu berupa penghargaan, pujian kepada kelompok yang terbaik dan memotivasi kelompok yang masih kurang. Selanjutnya, guru mempertegas materi, yaitu tentang bagian-bagian tabel, isi tabel, uraian tentang isi tabel dan menyimpulkan isi tabel.

Dalam tahap akhir pembelajaran dilakukan refleksi terhadap kesulitan yang dialami siswa saat proses pembelajaran dan memberikan motivasi kepada siswa untuk lebih bersemangat belajar

(2) Pertemuan Kedua

Pertemuan kedua sesuai dengan RPP 2. Pada pertemuan ini materi yang dibahas adalah perbedaan kalimat utama dan kalimat penjelas, serta informasi yang terdapat dalam bacaan. Seperti pada pertemuan pertama, pembelajaran dimulai dengan melaksanakan kegiatan awal. Dilanjutkan dengan melaksanakan kegiatan inti yang dimulai dengan melakukan tanya jawab mengenai paragraf, kalimat utama, pikiran utama dan kalimat penjelas yang ada dalam satu paragraf.

Pada tahap (Thinking) guru membagikan teks bacaan yang berjudul "Perempuan Lebih Rentan Osteoartritis". Siswa dipersilakan untuk membaca teks tersebut dalam hati secara intensif selama beberapa saat, kemudian diberikan soal yang berkaitan dengan isi bacaan yang harus diselesaikan siswa secara mandiri. Dilanjutkan dengan tahap berpasangan (Pairing) dengan kelompok yang sama seperti pertemuan pertama. Jalannya diskusi pada tahap (Pairing) sudah lebih baik dari pertemuan pertama. Tapi masih saja ada kelompok yang tidak mau bekerja sama. Setelah menyelesaikan permasalahan melalui diskusi kelompok siswa secara berpasangan berbagi tentang hasil diskusinya di depan kelas. Pada tahap ini sudah banyak kelompok yang angkat tangan untuk maju menyampaikan hasil diskusinya dengan kelompoknya masingmasing dan siswa yang lain juga sudah berani memberi tanggapan apa yang disampaikan temannya di depan kelas. Dilanjutkan dengan kegiatan menyimpulkan hasil diskusi, evaluasi, refleksi, dan memberikan motivasi. Pada pertemuan kedua, waktu yang dibutuhkan untuk mengorganisasikan siswa ke dalam kelompok belajar dan diskusi tidak selama seperti pada waktu pertemuan pertama. Namun masih melebihi batas waktu yang ditetapkan. Kendala dalam mengatur waktu masih dialami saat diskusi kelompok. Disamping itu, keterampilan siswa dalam mencari dan memberikan informasi kepada temannya masih kurang sehingga menghambat dalam proses diskusi dan pertukaran informasi. Pada tahap penyajian hasil kerja hanya sedikit waktu yang ada sehingga kegiatan penyimpulan hasil diskusi masih belum optimal.

(3) Pertemuan Ketiga

Pertemuan ketiga sesuai dengan RPP 3. Pada pertemuan ketiga, pembelajaran dimulai dengan melaksanakan kegiatan awal. Dilanjutkan dengan melaksanakan kegiatan inti yang dimulai dengan tanya jawab mengenai jenis-jenis paragraf berdasarkan letak kalimat utamanya, 
gagasan pokok, gagasan penjelas, membagikan teks bacaan yang berjudul "Bertanam Sayuran dalam Pot", mempersilakan siswa untuk membaca secara intensif selama beberapa saat dan menjawab soal yang berkaitan dengan isi bacaan secara mandiri, mengorganisasikan siswa untuk berkelompok secara berpasangan dengan teman sebangku, melakukan diskusi kelompok untuk menyelesaikan permasalahan.

Setelah melaksanakan diskusi kelompok siswa menyajikan hasil diskusinya masing-masing dan dilanjutkan dengan kegiatan penyimpulan hasil diskusi serta evaluasi pada akhir pembelajaran.

Pelaksanaan pembelajaran pada pertemuan ketiga ini sudah berjalan cukup baik. Siswa sudah mulai aktif dan bekerjasama dalam kelompok, namun kendala waktu tetap saja belum bisa diatasi secara maksimal, pada tahap thinking siswa selalu tidak bisa bekerja tepat dengan waktu yang disediakan, begitu juga pada saat diskusi kelompok.

(4) Pertemuan Keempat

Pertemuan keempat dilaksanakan pada hari Senin, 6 Februari 2017. Pada pertemuan ini siswa diuji kemampuan dan pemahamannya tentang materi yang telah dipelajari dengan tes akhir siklus I seperti pada lampiran 05. Waktu yang disediakan dalam tes ini adalah 60 menit. Kegiatan tes berlangsung lancar, meskipun terdapat beberapa siswa yang ribut, namun masih bisa ditanggulangi.

3) Observasi dan Evalusi Siklus I

Berdasarkan hasil observasi yang dilaksanakan setiap kali pembelajaran berlangsung, dapat dirangkum beberapa hal sebagai berikut.

(1) Dalam setiap kali pertemuan selama siklus I, rata-rata hanya 12 orang siswa yang tampak aktif dan antusias selama proses pembelajaran. Sedangkan siswa yang lain tampak kurang aktif dan kurang antusias.

(2) Dalam diskusi kelompok siswa rata- rata hanya 7 kelompok yang bekerja secara sungguhsungguh sedangkan siswa yang lain ada yang hanya mencontek pekerjaan temannya bahkan ada yang bermain-main saat diskusi kelompok.

(3) Interaksi siswa dalam diskusi kelas terutama saat penyajian hasil kerja masih tampak rendah. Rata-rata hanya 4 orang yang berani memberi tanggapan atas jawaban temannya dan mau bertanya atau mengemukakan pendapatnya.

Hasil yang diperoleh dari tes prestasi belajar dapat dijelaskan sebagai berikut: dari 26 orang siswa yang diteliti sudah 18 orang (72,00\%) yang memperoleh penilaian di atas KKM, sedangkan 8 orang $(38,00 \%)$ masih di bawah KKM.

4) Refleksi Siklus I

Hasil observasi yang diperoleh selama tindakan I kemudian evaluasi guna menyempurnakan tindakan selanjutnya. Semua dilakukan untuk dapat menunjukkan tingkat kemajuan-kemajuan yang dicapai, mencari kekurangan-kekurangan yang ada selama proses pelaksanaan tindakan, untuk dijadikan acuan perbaikan.

Refleksi dalam penelitian menurut para ahli menyangkut kegiatan analisis, sintesis, dan penilaian terhadap hasil pengamatan atas tindakan yang dilakukan (Hopkin, 1993 dalam Suharsimi Arikunto, Suhardjono, Supardi, 2006: 80). Penyajian dalam bentuk grafik/histogram seperti terlihat pada Gambar 1.

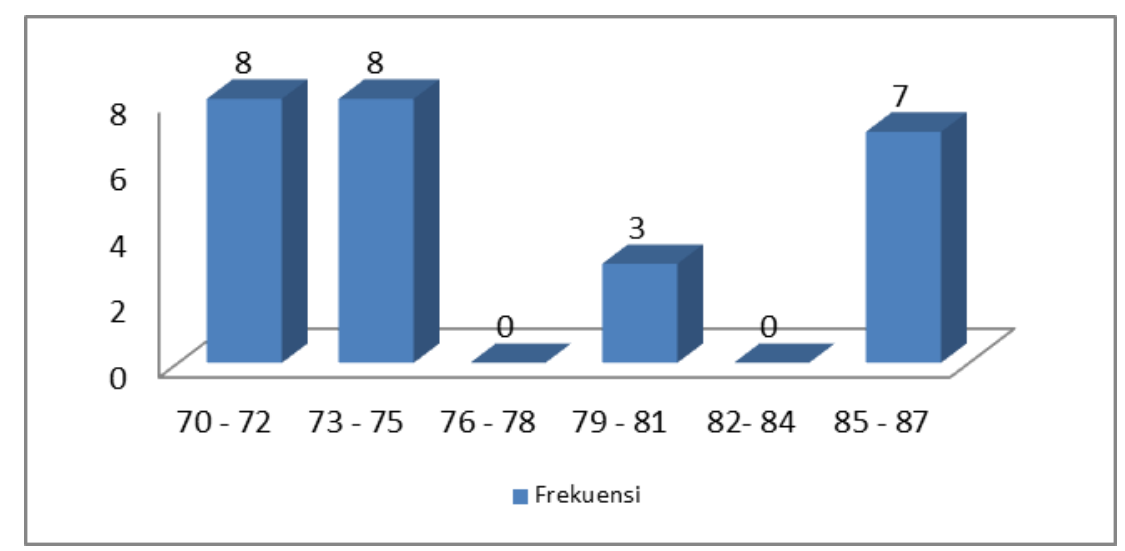

Gambar 1. Hasil Belajar Membaca Intensif Siswa Kelas VII A4 Semester Genap Tahun Pelajaran 2016/2017 Siklus I 
Hasil penilaian terhadap seluruh kegiatan penelitian yang sudah dilakukan pada Siklus I menunjukkan adanya kelemahan-kelemahan berikut.

(1) Siswa masih membutuhkan waktu yang lebih lama untuk terbiasa menyelesaikan kegiatannya menggunakan model pembelajaran yang baru.

(2) Sarana kurang memadai sehingga pembelajaran belum dapat dilaksanakan secara maksimal. Semua kekurangan yang telah disampaikan itu akan dibenahi selanjutnya pada Siklus ke II.

Pembelajaran pada Siklus II

1) Perencanaan Tindakan Siklus II

Sebagai upaya perbaikan tindakan untuk siklus II, peneliti mempersiapkan hal-hal yang pada dasarnya sama seperti pada siklus I. Materi yang dikaji dalam siklus II ini adalah teks bacaan dalam bentuk grafik dan teks biografi tokoh. Perencanaan tindakan pada siklus II disesuaikan dengan rumusan hasil refleksi pada siklus I. Pembelajaran pada siklus II dilaksanakan dengan menggunakan RPP (Rencana Pelaksanaan Pembelajaran) seperti dalam lampiran 09. Perbaikan yang dilaksanakan untuk mengatasi kendala pada siklus I adalah dengan merevisi rencana pelaksanaan pembelajaran, meningkatkan pengelolaan kelas. Kegiatan pembelajaran akan dilakukan dalam empat kali pertemuan, yaitu tiga kali pertemuan untuk kegiatan pembelajaran dan satu kali pertemuan untuk tes akhir siklus II.

2) Pelaksanaan Tindakan Siklus II

Siklus II dilaksanakan dalam empat kali pertemuan. Tiga kali untuk pembelajaran dan satu kali untuk tes akhir siklus II.

(1) Pertemuan pertama

Pada pertemuan ini materi yang dibahas adalah pemahaman terhadap ciri-ciri grafik, menguraikan data dengan kalimat, menyimpulkan isi grafik, dan menyusun uraian menjadi paragraf. Pembelajaran dimulai dengan melaksanakan kegiatan awal dan dilanjutkan dengan melaksanakan kegiatan inti yang dimulai dengan tanya jawab tentang ciri-ciri grafik, kalimat dari data dalam grafik, kesimpulan, dan cara menyusun paragraf. Selanjutnya guru menfasilitasi siswa dengan teks bacaan yang berjudul "Harga Beras di Tingkat Grosir Tahun 2007" siswa diberikan kesempatan untuk membaca teks tersebut secara intensif selama beberapa saat.

Memasuki tahap thinking siswa difasilitasi soal yang berkaitan dengan isi teks bacaan berbentuk grafik yang berjudul "Harga Beras di Tingkat Grosir tahun 2007 " dan mempersilakan untuk mengerjakan soal tersebut secara mandiri. Kemudian siswa diminta untuk berpasangan dengan teman sebangku (tahap Pairing) untuk mendiskusikan apa yang telah mereka kerjakan pada tahap thinking. Setelah waktu untuk diskusi dirasa cukup, beberapa pasangan diberi kesempatan untuk menyampaikan jawaban dari hasil diskusinya di depan kelas (sharing) sedangkan siswa yang lain memberi komentar. Dilanjutkan dengan pemberian penguatan pada siswa yang aktif dalam diskusi dan merangkum hasil diskusi.

Pelaksanaan pembelajaran pada pertemuan pertama siklus II ini sudah berlangsung lebih baik dibandingkan pada siklus I. Saat guru mengajukan pertanyaan, siswa sudah menunjukkan keaktifannya dan berusaha menyampaikan gagasan-gagasan atau pendapat-pendapat yang mereka miliki. Kendala waktu yang dialami pada siklus I sudah dapat diatasi walaupun masih ada beberapa siswa yang meminta waktu tambahan pada tahap Thinking. Saat diskusi kelompok berlangsung siswa sudah terlihat lebih berpartisipasi aktif memberikan pendapatpendapatnya, saat diskusi kelas sebagian besar siswa sudah berpartisipasi menanggapi apa yang disampaikan kelompok yang menyampaikan hasil diskusi di depan kelas. Namun, masih saja ada beberapa kelompok yang masih kesulitan menerima pendapat temannya dalam menyelesaikan permasalahan yang diberikan serta masih ada siswa yang terganggu dengan situasi di luar kelas.

(2) Pertemuan kedua

Pada pertemuan ini materi yang dibahas adalah pemahaman tentang riwayat hidup tokoh dan kesan yang diperoleh dari riwayat hidup tokoh. Pembelajaran dimulai dengan melaksanakan kegiatan awal dan dilanjutkan dengan melaksanakan kegiatan inti yang dimulai dengan tanya jawab tentang riwayat hidup tokoh dan kesan yang diperoleh dari riwayat hidup tokoh. Selanjutnya guru menfasilitasi siswa dengan teks bacaan yang berjudul "Cut Nyak Dien" siswa diberikan kesempatan untuk membaca teks tersebut secara intensif selama beberapa saat.

Memasuki tahap thinking siswa difasilitasi soal yang berkaitan dengan isi teks bacaan yang berjudul "Cut Nyak Dien" dan mempersilakan untuk mengerjakan soal tersebut secara mandiri. Kemudian siswa diminta untuk berpasangan dengan teman sebangku (tahap Pairing) untuk mendiskusikan apa yang telah mereka kerjakan pada tahap thinking. Setelah waktu untuk 
diskusi dirasa cukup, beberapa pasangan diberi kesempatan untuk menyampaikan jawaban dari hasil diskusinya di depan kelas (sharing) sedangkan siswa yang lain memberi komentar. Dilanjutkan dengan pemberian penguatan pada siswa yang aktif dalam diskusi dan merangkum hasil diskusi.

Pelaksanaan pembelajaran pada pertemuan kedua siklus II ini sudah berlangsung lebih baik dibandingkan pertemuan pertama. Kendala waktu pada pertemuan ini bisa dibilang sudah teratasi dengan baik, tidak ada lagi siswa yang mengeluh minta perpenjangan waktu. Saat diskusi kelas sebagai besar siswa sudah berpartisipasi menanggapi apa yang disampaikan kelompok yang menyampaikan hasil diskusi di depan kelas, walau masih ada beberapa siswa yang kurang menyimak saat diskusi kelas karena terganggu dengan keadaan di luar kelas.

(3) Pertemuan ketiga

Pada pertemuan ini materi yang dibahas adalah sikap dan tindakan yang dapat diteladani dari tokoh. Pembelajaran dimulai dengan melaksanakan kegiatan awal dan dilanjutkan dengan melaksanakan kegiatan inti yang dimulai dengan tanya jawab tentang pengertian sikap dan tindakan. Selanjutnya guru menfasilitasi siswa dengan teks bacaan yang berjudul "Raden Ajeng Kartini" siswa diberikan kesempatan untuk membaca teks tersebut secara intensif selama beberapa saat.

Memasuki tahap thinking siswa difasilitasi soal yang berkaitan dengan isi teks bacaan yang berjudul "Raden Ajeng Kartini" dan mempersilakan untuk mengerjakan soal tersebut secara mandiri. Kemudian siswa diminta untuk berpasangan dengan teman sebangku (tahap Pairing) untuk mendiskusikan apa yang telah mereka kerjakan pada tahap thinking. Setelah waktu untuk diskusi dirasa cukup, beberapa pasangan diberi kesempatan untuk menyampaikan jawaban dari hasil diskusinya di depan kelas (sharing) sedangkan siswa yang lain memberi komentar. Dilanjutkan dengan pemberian penguatan pada siswa yang aktif dalam diskusi dan merangkum hasil diskusi.

Pelaksanaan pembelajaran pada pertemuan ke tiga siklus II ini sudah berlangsung lebih baik dibandingkan pada siklus I. Saat guru mengajukan pertanyaan, siswa sudah menunjukkan keaktifannya dan berusaha menyampaikan gagasan-gagasan atau pendapat-pendapat yang mereka miliki. Saat diskusi kelompok berlangsung siswa sudah terlihat lebih berpartisipasi aktif memberikan pendapat-pendapatnya, saat diskusi kelas sebagai besar siswa sudah berpartisipasi menanggapi apa yang disampaikan kelompok yang menyampaikan hasil diskusi di depan kelas. Namun, masih saja ada beberapa kelompok yang masih kesulitan menerima pendapat temannya dalam menyelesaikan permasalahan yang diberikan serta masih ada siswa yang terganggu dengan situasi di luar kelas.

Secara umum kegiatan pembelajaran pada pertemuan ke tiga yang merupakan pertemuan terakhir dari siklus II ini berlangsung sesuai dengan yang direncanakan. Siswa sudah aktif menanggapi pertanyaan-pertanyaan yang diajukan oleh guru. Kerja sama siswa dalam diskusi kelompok sudah sangat baik. Saat diskusi kelas sebagian besar siswa sudah berpartisipasi menanggapi apa yang disampaikan kepada kelompok yang menyampaikan hasil diskusi di depan kelas.

(4) Pertemuan keempat

Pada pertemuan ini siswa diuji kemampuan dan pemahamannya tentang materi yang telah dipelajari dengan tes akhir siklus II seperti pada lampiran 12. Sistem ulangan yang dilaksanakan sama dengan yang diterapkan pada siklus I, yaitu dengan menerapkan sistem tutup buku dan tidak diperkenankan bekerja sama. Waktu yang disediakan dalam tes ini adalah 60 menit.

3) Observasi/Pengamatan II

Untuk mengetahui sejauh mana tingkat perkembangan mereka, guru menggunakan pengamatan lewat tes prestasi belajar.

4) Refleksi Siklus II

Data yang diperoleh dari hasil penilaian tes hasil belajar dapat dijelaskan bahwa dari 26 orang siswa, 26 siswa (100\%) memperoleh nilai memenuhi bahkan diatas KKM. Gambaran yang dapat disampaikan adalah mereka sangat berkembang yang artinya bahwa mereka mampu menyelesaikan tugas dengan baik. Hasil observasi pada siklus II ini ternyata sudah menunjukkan keberhasilan sesuai tuntutan indikator keberhasilan penelitian seperti terlihat pada Gambar 2. 


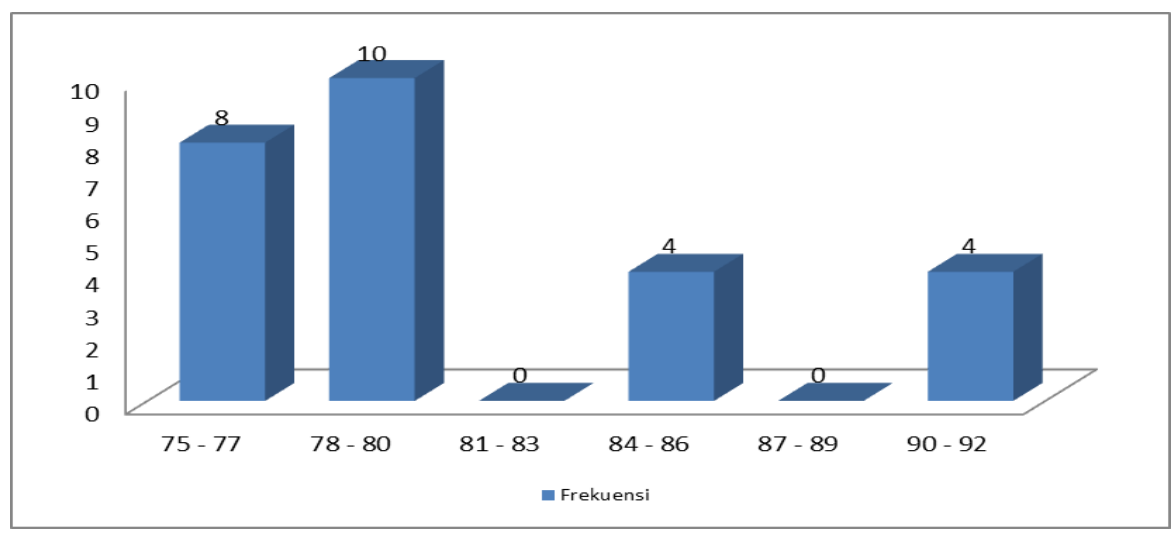

Gambar 2. Hasil Belajar Membaca Intensif Siswa Kelas VII A4 Semester GenapTahun Pelajaran 2016/2017 Siklus II

Penilaian terhadap seluruh kegiatan penelitian yang sudah dilakukan pada Siklus II perlu dijelaskan bahwa pada Siklus II ini semua indikator yang dituntut dalam pembelajaran telah secara tuntas dapat dilaksanakan. Semua kekurangan-kekurangan yang ada pada siklus sebelumnya sudah diperbaiki pada siklus ini, sehingga tidak ada yang masih perlu diragukan bahwa indikator yang dituntut untuk diselesaikan tidak ada lagi yang tertinggal. Semua hasil yang diperoleh pada Siklus II ini menunjukkan bahwa penelitian ini tidak perlu dilanjutkan lagi ke siklus berikutnya karena keberhasilan yang dituntut agar peserta didik mencapai ketuntasan belajar minimal 80\% sudah terpenuhi dengan hasil yang diperoleh sudah tercapai $100 \%$.

Penelitian tindakan kelas dilaksanakan selama 2 siklus ini menunjukkan terjadinya peningkatan hasil belajar membaca intensif pada siswa kelas VII A4 Semester II Tahun pelajaran 2016/2017. Penelitian ini menerapkan Strategi Pembelajaran Think Pair Share.

Berdasarkan refleksi awal, kemampuan siswa dalam aspek membaca khususnya membaca intensif masih tergolong kurang. Pola belajar siswa di kelas lebih banyak didominasi oleh guru dan sesekali guru melemparkan pertanyaan kepada siswa. Siswa jarang diberikan belajar secara berkelompok dan melakukan diskusi kelas. Mereka cenderung belajar sendiri tanpa adanya tukar informasi antara siswa yang satu dengan siswa yang lain, sehingga interaksi dan komunikasi antar siswa di dalam kelas belum berjalan secara optimal.

Sebelum pelaksanaan tindakan, jumlah siswa yang tuntas adalah 10 orang atau 38,46\% dengan rata-rata presentase tingkat hasil belajar membaca intensif siswa sebesar 73,08\%, jika dikonversikan pada pedoman konversi PAP skala lima berada pada katagori cukup. Kemudian pada siklus I jumlah siswa yang tuntas adalah 18 orang atau 69,23\% rata-rata presentase tingkat hasil belajar membaca intensif siswa sebesar 76,73\% dan jika dikonversikan pada pedoman konversi PAP skala lima berada pada katagori cukup. Sesuai dengan target peneliti, penelitian dikatakan berhasil apabila siswa secara klasikal memperoleh rata-rata persentase kemampuan membaca intensif $\geq 75 \%$ dengan pencapaian tingkat hasil belajar pada kategori cukup. Rata-rata persentase nilai dari membaca intensif siswa pada siklus I sudah di atas dari 75\% yakni sebesar 73,57\% namun ketuntasan belajar klasikal masih di bawah $80 \%$ yaitu 72,00\%. Jadi, pencapaian hasil belajar pada siklus I ini belum tuntas karena belum memenuhi target yang ditentukan ketuntasan belajar klasikal $\geq 80 \%$. Untuk itu, perlu dilakukan perbaikan-perbaikan dalam pelaksanaan pembelajaran yang sesuai dengan kekurangan maupun kendala-kendala yang ditemukan saat pelaksanaan pembelajaran pada siklus I.

Belum tuntasnya hasil belajar siswa pada siklus I ini diduga merupakan akibat dari beberapa faktor sebagai berikut.

1) Keaktifan siswa dalam menanggapi pertanyaan dari guru masih kurang optimal, terutama pada pertemuan-pertemuan awal. Siswa masih ragu-ragu dalam mengajukan pendapat atau gagasannya. Mereka masih takut jika jawaban yang disampaikan salah.

2) Pada saat pembagian kelompok kebanyakan siswa tidak setuju dipasangankan dengan teman sebangkunya, sehingga suasana menjadi ricuh dan waktu lebih lama terlewatkan untuk memasangkan siswa.

3) Kegiatan diskusi kelompok dan diskusi kelas belum sepenuhnya efektif, dalam hal ini siswa kurang aktif dalam mengemukakan pendapat dan hanya mengandalkan pendapat teman yang pintar dari kelompoknya. Ada beberapa siswa yang hanya diam menunggu jawaban teman dalam kelompoknya tanpa menghiraukan kebenaran dari jawaban tersebut. 
4) Masih banyak siswa yang mengalami kesulitan dalam menemukan kalimat utama dalam setiap paragraf.

5) Waktu masih merupakan kendala utama. Banyak waktu terbuang hanya untuk membentuk kelompok, serta ketidakdisiplinan siswa memanfaatkan waktu pada tahap Thinking maupun pada tahap Pairing.

Berdasarkan hasil refleksi siklus I, maka pelaksanaan tindakan pada siklus II mengacu pada perbaikan dan penyempurnaan terhadap tindakan yang telah berlangsung pada siklus I. Upaya-upaya perbaikan pada siklus II adalah sebagai berikut.

1) Memberikan motivasi, penguatan berupa pujian bagi siswa yang sudah berani menjawab atau memberikan pendapat.

2) Mengatur komposisi kelompok secara heterogen. Karena jika siswa dikelompokan atau dipasangkan dengan teman sebangkunya, kebanyakan siswa duduk dengan tingkat kemampuan yang homogen.

3) Memberikan pertanyaan atau pernyataan yang dapat dijadikan acuan oleh siswa dalam memberikan pendapatnya. Dengan melakukan upaya seperti itu diharapkan dapat memberikan motivasi yang positif kepada siswa.

4) Lebih memberikan bimbingan dan penekanan saat diskusi kelompok maupun penyimpulan tentang ciri kalimat utama dan kalimat penjelas.

5) Mempertegas waktu yang disediakan pada setiap tahapan.

Upaya-upaya perbaikan yang dilakukan pada siklus II menunjukkan hasil yang positif. Hal ini terlihat dari jumlah siswa yang tuntas pada siklus II sudah mencapai 26 orang atau semua siswa dan nilai rata-rata dari membaca intensif pada siklus II sudah mengalami peningkatan, yaitu persentase tingkat hasil belajar membaca intensif siswa menjadi sebesar $100 \%$. Jika persentase hasil belajar siswa tersebut dikonversikan pada PAP skala lima maka berada pada interval persentase 80 - 89 dengan pencapaian tingkat hasil membaca intensif pada kategori baik. Dengan demikian dapat disimpulkan bahwa penerapan strategi pembelajaran Think Pair share sudah berhasil meningkatkan hasil belajar membaca intensif siswa. Terbukti rata-rata presentase secara klasikal meningkat (pada refleksi awal 73,08\% dengan ketuntasan $38,46 \%$ menjadi $76,73 \%$ dengan ketuntasan $72 \%$ pada siklus I dan menjadi $80,77 \%$ dengan ketuntasan $100 \%$ pada siklus II).

\section{Simpulan dan saran}

Berdasarkan hasil penelitian dan pembahasan yang telah diuraikan, dapat disimpulkan bahwa Penerapan strategi pembelajaran Think Pair Share dapat meningkatkan hasil belajar membaca intensif siswa pada siswa kelas VII A4 SMP Negeri 3 Sawan Semester Genap Tahun Pelajaran 2016/2017. Hal ini dapat dilihat dari semakin meningkatnya hasil belajar membaca intensif siswa. Pada refleksi awal ratarata nilai membaca intensif siswa sebesar 69,82 dengan ketuntasan $42,86 \%$ dan pada siklus I nilai ratarata siswa meningkat menjadi 73,57 dengan ketuntasan 67,86\% walaupun masih dalam kategori cukup tapi sudah ada peningkatan pada nilai rata-rata siswa sebesar 3,75\%. Setelah dilaksanakan perbaikan tindakan pada siklus II, rata-rata nilai membaca intensif siswa pada siklus II sebesar 80,36 mengalami peningkatan sebesar 6,79\% dari Siklus I dan berada pada kategori baik dan seluruh siswa tuntas.

Mengacu kepada temuan penelitian ini, dapat dikemukakan beberapa saran sebagai berikut. Pertama, dengan berhasilnya pelaksanaan penelitian ini, kepada guru mata pelajaran Bahasa Indonesia diharapkan dapat menerapkan strategi pembelajaran Think Pair Share dalam menanggulangi permasalahan kegiatan pembelajaran Bahasa Indonesia khususnya dalam membaca intensif. Kepada pembaca yang berminat untuk mengadakan penelitian lebih lanjut mengenai penerapan strategi pembelajaran Think Pair Share pada pada bidang ilmu Bahasa Indonesia ataupun pada bidang ilmu yang lain, agar memperhatikan segala kendala ataupun kekurangan-kekurangan sebagai bahan pertimbangan untuk menyempurnakan pelaksanaan penelitian. Kepada sekolah, agar memberikan kesempatan serta fasilitas penunjang kepada guru mata pelajaran dalam mencoba menanggulangi permasalahan pembelajaran dengan menggunakan strategi ini, sehingga kualitas output pendidikan dapat ditingkatkan.

\section{Daftar Rujukan}

Arifin, Z. 2012. Evaluasi Pembelajaran. Bandung: PT. Remaja Rosdakarya.

Arikunto, S., Suhardjono dan Supardi. 2006. Penelitian Tindakan Kelas. Jakarta: PT Bumi Aksara.

Depdiknas. 2005. Kamus Besar Bahasa Indonesia. Jakarta: Balai Pustaka. 
Ekawati , I Gusti Ayu Putu Raka.2013. "Implementasi Model Kooperatif TPS Meningkatkan Aktivitas Dan Hasil Belajar Berguling Senam Lantai'. Jurnal Pendidikan Jasmani, Olahraga Dan Kesehatan Undiksha Vol 1, No 4 (2013).

Jasdilla, L, Kuswendi, U, Ramdhani.2017.Hasil Belajar Dan Pembelajaran Kooperatif Tipe Tps. Jurnal Pendidikan Indonesia Vol. 6, No.1, April 2017 | 96

Maksum, A. 2006. Pengaruh Metode Pembelajaran Inquiri terhadap Hasil Belajar Sejarah dan Sikap Nasionalisme Siswa Kelas XI SMA Negeri1 Sukamulia, Lombok Timur, NTB. Tesis. Program Pascasarjana Universitas Pendidikan Ganesha Singaraja.

Modern Educators and Lexicographers. 1939. Webster's New American Detionary. New York: 140 Broadway, Books, Inc.

Nasution. S. 2006. Berbagai Pendekatan Dalam Proses Belajar Mengajar. Jakarta: Rineka Cipta.

Nida, I Gd. W. \& I Nym. Pt. Suwindra, I. Suswandi. 2014." Pengaruh Model Pembelajaran Kooperatif Tipe TPS (Think Pair Share) Berbantuan Peta Konsep Terhadap Prestasi Belajar Fisika". Wahana Matematika Dan Sains: Jurnal Matematika, Sains, Dan Pembelajarannya Vol 8, No 2 (2014): Oktober 2014.

Poerwadarminta, W.J.S. 2003. Kamus Umum Bahasa Indonesia. Jakarta: Balai Pustaka.

Pusat Bahasa Departemen Pendidikan Nasional. 2005. Kamus Besar Bahasa Indonesia. Jakarta: Balai Pustaka.

Putrayasa, I. B. 2005. Pembelajaran Bahasa Indonesia Berbasis Inquiri dalam Upaya Meningkatkan Aktivitas, Kreativitas, dan Logikalitas. Tesis. Institut Keguruan dan Ilmu Pendidikan Negeri Singaraja.

Sardiman, A.M. 2009. Interaksi dan Motivasi Belajar Mengajar. Jakarta: PT. Raja Grafindo Persada

Sardiman, A.M. 2011. Interaksi \& Motivasi Belajar Mengajar. Jakarta: PT. Raja Grafindo Perkasa.

Sugihartono, dkk. 2007. Psikologi Pendidikan. Yogyakarta: UNY Press.

Sukidin, Basrowi, dan Suranto. 2002. Menajemen Penelitian Tindakan Kelas. Penerbti: Insan Cendekia.

Suryabrata, S. 2002. Psikologi Pendidikan. Jakarta : PT. Raja Grafindo Persada.

Suryabrata, S. 2006. Psikologi Kepribadian. Jakarta: Raja Grafindo Persada.

Sutrisno, T. (2016). Penerapan Model Pembelajaran Kooperatif Tipe Think pair share Dengan Media Visual Dalam Peningkatan Hasil Belajar IPS Pada Siswa Kelas Iii Sd Negeri 7 Kutosari Tahun Ajaran 20152016. Kalam Cendekia, 4(6.1), 730-734.

Tirtonegoro, S. 2001. Penelitian Hasil Belajar Mengajar. Surabaya: Usaha Nasional.

Winantara, I W Daniel \& I Nyoman Laba Jayanta. 2017. "Penerapan Model Pembelajaran TPS untuk Meningkatkan Hasil Belajar IPA Siswa Kelas V SD No 1 Mengwitani”. Jurnal Ilmiah Sekolah Dasar Vol 1, No 1 (2017): Februari 2017.

Zuddin , Mufari.2018. "The Improvement Of Learning Result Of Pkn By Using Think Pair Share (TPS) Of Primary School Students". JPI (Jurnal Pendidikan Indonesia) Vol 7, № 2 (2018). 